\title{
Dark traits from the variable-centered and person-centered approach and their relations with some risky behaviours ${ }^{1}$
}

\author{
Bojana M. Dinić2 , Mina Velimirović, Selka Sadiković \\ Department of Psychology, Faculty of Philosophy, \\ University of Novi Sad, Serbia
}

The aim of this research was to determine whether the person-centered or the variable-centered approach is better at describing the covariance between the Dark Triad and Dark Tetrad traits in the community sample. On the sample of 624 participants (48.2\% males), the Dark Triad Dirty Dozen (DTDD), the Short Sadistic Impulse Scale (SSIS) and the Varieties of Sadistic Tendencies Scale (VAST) were used for measuring the dark traits, while the Reactive Proactive Questionnaire (RPQ) and the questions about alcohol use were applied for criteria validation. In order to test whether the variable- or the person-centered approach better described covariance among the dark traits, the latent profile analysis was used. The results revealed one profile or two quantitatively different profiles (low and high dark traits), suggesting that the variable-centered approach is more appropriate than the person-centered for describing the dark traits. In the case of the Dark Tetrad, profile membership largely depended on the used sadism measure, i.e. profile agreement was moderate. High dark traits profile based on the combination with the SSIS sadism scale was characterized by both higher aggression and alcohol use, while the same profile based on the combination with the VAST sadism measure was characterized only by higher aggression.

Key words: Dark Triad, Dark Tetrad, dark traits, sadism, latent profile analysis, aggression, alcohol use

\footnotetext{
1 This paper is part of the project "Hereditary, Environmental and Psychological Factors of Mental Health" (179006) funded by the Ministry of Education, Science and Technological Develpoment, Republic of Serbia

2 bojana.dinic@ff.uns.ac.rs
} 


\section{Variable-centered and person-centered approach}

Over the years, the majority of personality research studies have employed the variable-centered approach. The focus of this approach is on the differences among individuals on the variables or associations between the predictor and outcome variables (Malmberg et al., 2012). According to the variable-centered approach, any given trait manifests itself in the same way across a population of individuals. In other words, variable-centered models are based on the assumption that the population is homogenous. Although the studies conducted within this approach are of great importance for advancing our understanding of particular personality traits, its drawback is that it does not allow for the exploration of complex configurations of variables within individuals (Bergman \& Trost, 2006). The alternative approach is the personcentered approach by which individuals who share similar patterns of traits could be identified, and the population could be divided into homogeneous subgroups with distinct trait profiles. One of the advantages of the personcentered over the variable-centered approach is that this approach allows qualitatively different groups of participants to be extracted. Contrary to the variable-centered approaches, the assumption of the person-centered approach is that a particular trait might be expressed differently in the context of the strength of other traits (Meyer \& Morin, 2016). Therefore, it is suggested that the variable-centered and person-centered approaches should be combined in order to foster a better understanding of the processes and patterns underlying behaviour (e.g., Asendorpf \& Denissen, 2006).

\section{Dark traits}

Paulhus and Williams (2002) introduced the Dark Triad constellation, comprised of three socially malevolent traits: narcissism, Machiavellianism, and psychopathy. Narcissism is characterized by a grandiose sense of self, entitlement, dominance, and superiority; Machiavellianism by manipulativeness, callous affect, strategic planning, and superior impulse regulation; and psychopathy by thrill-seeking, lack of empathy and remorse, superficial charm, low anxiety proneness, and a lack of long-term goals (e.g., Jones \& Paulhus, 2014; Muris, Merckelbach, Otgaar, \& Meijer, 2017). The fourth dark trait, sadism, was later added to the Triad, forming a Dark Tetrad (Chabrol, Van Leeuwen, Rodgers, \& Séjourné, 2009). In the first proposed measure of everyday sadism, the Short Sadistic Impulse Scale (SSIS; O'Meara, Davies, \& Hammond, 2011), sadistic personality is characterized by a longstanding pattern of cruel behaviour. Humiliating, or intentionally inflicting psychical, sexual, or psychological harm to others are all means by which everyday sadists assert power, dominance, or pleasure and enjoyment. Thus, by this definition, sadism includes not only instrumentally-motivated, 
but also anger-motivated aggression. However, Paulhus and Jones (2015) have suggested a different measure of sadism - the Varieties of Sadistic Tendencies scale (VAST). In the VAST, the key element of everyday sadism is an intrinsic enjoyment of hurting others. According to these authors, sadistic behaviours can take two forms: direct and vicarious. Direct or "core" sadism refers to enjoyment while personally inflicting suffering to others, and it is conceptually close to the SSIS operationalization of sadism. On the other hand, vicarious sadism refers to the joy of watching others commit sadistic acts or watching cruel scenes in movies, games, etc.

\section{Dark traits in the person-centered approach}

Personality traits are assumed to be continuous, which is why the variable-centered approach is usually applied within the field of personality psychology. On the other hand, the nature of clinical disorders is assumed to be taxonic, which is why the person-centered approach is more frequently applied in this field (Foster \& Campbell, 2007). These differences are worth mentioning since it is assumed that the concept of the Dark Tetrad falls somewhere in between personality and clinical psychology. In other words, the dark traits are considered to be subclinical (Paulhus, 2014). Due to the subclinical nature of the dark traits, it seems that both the variable- and person-centered approach might provide the researchers with valuable insights about dark traits.

The research on dark personality traits is rapidly expanding (Muris et al., 2017). However, there is still a small number of studies on the dark traits where the person-centered approach has been applied (Chabrol, Melioli, Van Leeuwen, Rodgers, \& Goutaudier, 2015; Kam \& Zhou, 2016). Moreover, the existing studies showed inconsistent results. In the first study, which was conducted with the aim to identify a typology of high-school students based on the Dark Tetrad traits, cluster analysis yielded four groups: the low dark traits group, the Machiavellian group, the narcissistic group, and the Dark Tetrad cluster, which was high on all four traits (Chabrol et al., 2015). According to these findings, qualitatively different groups can be extracted. In the second study, parallel shapes of the Dark Triad profile solutions (high, middle, and low Dark Triad traits) were extracted, meaning that the profiles differed only quantitatively, not qualitatively (Kam \& Zhou, 2016). However, different constructs were examined in the two studies - the first study examined the Dark Tetrad, whereas the second examined the Dark Triad. Moreover, different analyses were applied - the traditional cluster analysis in the first study, and latent profile analysis (LPA) in the second study. The advantages of LPA over cluster analysis are that LPA does not force the solution with a relatively equal number of participants in groups and 
allows a one-group solution. The possibility of getting a one-group solution is particularly important since the extraction of only one group would indicate that the variable-centered approach is more appropriate than the personcentered approach (Meehl, 1992; Sadiković, Fesl, \& Coolović, 2016). Moreover, if more than one profile was extracted, but the differences between the extracted profiles were quantitative and not qualitative, the variable-centered approach would be more appropriate.

\section{The present study}

Due to the inconsistent results of the previous studies, the aim of this study was to access the Dark Triad and Dark Tetrad traits from both the variablecentered and person-centered approach. In this study, we used latent profile analysis in order to test which of the two approaches aligned better with the description of the dark traits. We wanted to examine how many profiles would be extracted, and whether the profiles would differ only quantitatively or qualitatively, i.e. whether the variable- or person-centered approach better described the relations between the dark traits. Since these traits are considered to be subclinical (Paulhus, 2014), i.e. they manifest both general and clinical personality characteristics, the extraction of qualitatively different profiles would be potentially valuable information of the status of the dark traits.

Moreover, in order to validate the extracted solutions, the relations with the risky behaviours, aggression and alcohol use were explored. Many studies that employed the variable-centered approach have shown that the dark traits are associated with antisocial behaviour (e.g., Furnham, Richards, \& Paulhus, 2013), as well as with alcohol and drug use (e.g., Jonason, Koenig, \& Tost, 2010). Moreover, the dark traits are related both to the proactive and reactive aggression (e.g., Dinić \& Wertag, 2018; Reidy, Foster, \& Zeichner, 2010, Reidy, Zeichner, \& Seibert, 2011). However, the studies have shown that not all dark traits are equally "dark". In the situations when aggression is unprovoked and costly in terms of time and effort only sadists will aggress (Buckels, Jones, \& Paullhus, 2013), which indicates that sadism might be the "darkest" of the four traits. Furthermore, Machiavellianism and narcissism seem to be "lighter" than psychopathy in terms of their relations to alcohol, cigarette, and drug abuse, as well as risky sexual behaviours (e.g., Jonason et al., 2010). In one study in which the person-centered approach was used, the high Dark Tetrad cluster was characterized by the highest level of antisocial behaviours, and together with the narcissistic cluster had a higher level of cannabis use compared to other clusters (Chabrol et al., 2015). Thus, in a specific combination of other dark traits, narcissism seems "dark" as the other dark traits. Therefore, the relations between risky behaviours on the one side, and variable- and person-centered solutions on the other, could provide a better insight into the malevolence of each dark trait, as well as into their mutual configurations. Moreover, we could 
obtain insight into how informative each approach is, i.e. whether one approach gives additional information about the relations with risky behaviours, or both are equally informative, in which case we could keep a more parsimonious approach (i.e., the variable-centered approach).

\section{Method}

\section{Participants and procedure}

The sample included 624 participants, aged from 18 to $76(M=32.6, S D$ $=12.8)$. The proportions of males $(48.2 \%)$ and females $(51.8 \%)$ were roughly equal. A convenient sampling method was used. The data were collected by trained undergraduate psychology students as part of their pre-exam activities. In order to get a heterogeneous sample, each student had to collect the data from a specific number of participants, based on given sex and age quotas. Participants completed the questionnaires at their homes, in the presence of the examiner. The sample was used in Dinić and Raine's (2019) study, but with different instruments and purpose of the study. The study was approved by the Institutional Review Board.

\section{Instruments}

The Dark Triad Dirty Dozen (DTDD; Jonason \& Webster, 2010, for Serbian adaptation see Dinić, Petrović, \& Jonason, 2018) was used as a measure of Machiavellianism, narcissism and psychopathy. The DTDD contains 12 items in total (4 items per trait).

The Short Sadistic Impulse Scale (SSIS; O'Meara et al., 2011, for Serbian adaptation see Dinić, Bulut, Petrović, \& Wertag, under review) contains 10 items, and was used as a measure of sadistic inclinations and impulses.

The Varieties of Sadistic Tendencies Scale (VAST; Paulhus \& Jones, 2015, for Serbian adaptation see Dinić et al., under review) was used as a measure of everyday sadism. The VAST Scale consists of 7 items which measure direct or "core" sadism (enjoyment derived from hurting or humiliating others) and 9 items which measure indirect or vicarious sadism (enjoyment derived from witnessing other people's suffering).

The Reactive Proactive Questionnaire (RPQ; Raine et al., 2006, for Serbian adaptation see Dinić \& Raine, 2019) was used for measuring reactive (11 items) and proactive aggression (12 items). Each item, i.e. aggressive behaviour, was rated on a 3 -point scale $(0=$ never, $1=$ sometimes, and $2=$ often $)$. The correlation between reactive and proactive aggression was .60 ( $p<.001)$.

Besides the RPQ, all items were answered on a 5-point scale, from $1=$ completely disagree to $5=$ completely agree (or the frequency rating the case of alcohol consummation). Descriptives and reliabilities are presented in Table 1. 
Alcohol use and binge drinking were assessed by two questions: 1) How often do you use alcohol? and 2) How often do you binge drink? Participants rated the frequency of alcohol use and abuse on a 5-point scale, from $1=$ never to $5=$ often.

\section{Data analysis}

First, descriptives and alpha reliabilities were calculated, as well as intercorrelations between the dark traits, and correlations between the dark traits and criteria variables (aggression and alcohol related behaviours). Second, in order to identify the distinct groups of participants based on the Dark Tetrad traits, latent profile analysis (LPA) was applied in the "mclust" package for the R environment (Fraley, Raftery, Murphy, \& Scrucca, 2012). This statistical procedure compares the models with a variety of latent categories taking into account all combinations of characteristics distribution (spherical, diagonal and ellipsoidal), volumes (variable or equal), shape (variable or equal), and orientation (parallel with coordinate axes, variable or equal). To assess the optimal number of latent categories, the Bayesian information criterion was used (Fraley et al., 2012), with higher BIC values pointing to a more adequate model (Raftery, 1995). Differences in the dark traits between profiles were tested by $t$-tests and Cohen's $d$ was calculated as a measure of the effect size. A commonly used interpretation is to refer to effect sizes as small $(d=0.20)$, medium $(d=0.50)$, and large $(d=0.80)$, based on the benchmarks suggested by Cohen (1988). For the agreement among profile solutions based on different measurements, Cohen's kappa was calculated with values .50 and higher being interpreted as moderate, .70 and higher as good and .80 and higher as very good agreement (Peat, 2001). Third, since previous studies have shown the effect of sex and age on the dark traits (e.g., Dinić et al., 2018), in this study sex differences in profiles were tested by $\chi^{2}$ tests, and age differences by $t$-tests in order to test their effects. Since the analyses confirmed their effects, sex and age were entered into the model as covariates in order to control for their effects. Differences in risky behaviours among profiles were tested by the univariate general linear model. In this analysis, partial eta squared $\left(\eta_{\mathrm{p}}{ }^{2}\right)$ was used as a measure of the effect size. Cohen (1988) has provided benchmarks to define small $\left(\eta_{\mathrm{p}}{ }^{2}=0.01\right)$, medium $\left(\eta_{\mathrm{p}}^{2}=0.06\right)$, and large $\left(\eta_{\mathrm{p}}^{2}=0.14\right)$ effects.

\section{Results}

\section{Descriptives and correlations}

There were significant, large differences between the dark traits scores $\left(F_{(3.84,2390.23)}=497.80, p<.001, \eta_{p}^{2}=0.44\right)$. Post hoc Bonferroni tests showed that the only non-significant difference was between Machiavellianism and 
psychopathy $(p=.21)$; the scores on Machiavellinism were the highest, while the scores on SSIS sadism were the lowest (Table 1). As a milder form of sadism, vicarious sadism had the highest score among all sadism variables. Results also showed that sadism generally had lower intercorrelations with the other three dark traits. All correlations between the Dark Triad traits were high and around .60 , which indicates that these three traits shared minimum $32 \%$ of the variance, which corresponds to a minimum correlation between two dark traits (.57).

Table 1

Descriptives and correlations among the dark traits

\begin{tabular}{|c|c|c|c|c|c|c|c|c|c|c|c|}
\hline \multirow{2}{*}{\multicolumn{2}{|c|}{ Measures }} & \multicolumn{3}{|c|}{ DTDD } & \multirow[t]{2}{*}{ SSIS } & \multirow[b]{2}{*}{ DS } & \multirow[b]{2}{*}{ VS } & \multirow[b]{2}{*}{ VAST total } & \multirow[b]{2}{*}{$M$} & \multirow[b]{2}{*}{$S D$} & \multirow[b]{2}{*}{$\alpha$} \\
\hline & & $\mathrm{M}$ & $\mathrm{N}$ & $\mathrm{P}$ & & & & & & & \\
\hline \multirow[t]{3}{*}{ DTDD } & $\mathrm{M}$ & 1 & & & & & & & 2.68 & 0.66 & .81 \\
\hline & $\mathrm{N}$ & .59 & 1 & & & & & & 2.40 & 0.73 & .65 \\
\hline & $\mathrm{P}$ & .59 & .57 & 1 & & & & & 2.33 & 0.65 & .54 \\
\hline SSIS & & .33 & .38 & .36 & 1 & & & & 1.55 & 0.49 & .82 \\
\hline \multirow[t]{3}{*}{ VAST } & DS & .27 & .21 & .25 & .43 & 1 & & & 1.81 & 0.39 & .64 \\
\hline & VS & .26 & .31 & .21 & .48 & .44 & 1 & & 2.13 & 0.52 & .77 \\
\hline & VAST total & .31 & .31 & .27 & .54 & .80 & .89 & 1 & 1.97 & 0.39 & .80 \\
\hline \multirow[t]{2}{*}{ RPQ } & Reactive agg. & .28 & .34 & .17 & .28 & .13 & .22 & .21 & 0.75 & 0.34 & .81 \\
\hline & Proactive agg. & .32 & .34 & .23 & .37 & .24 & .31 & .33 & 0.16 & 0.23 & .82 \\
\hline \multicolumn{2}{|c|}{ Alcohol use } & .07 & .08 & .05 & .17 & .15 & .18 & .20 & 2.17 & 0.86 & - \\
\hline \multicolumn{2}{|c|}{ Binge drinking } & .16 & .15 & .15 & .21 & .17 & .28 & .27 & 1.57 & 0.69 & - \\
\hline
\end{tabular}

Note. M - Machiavellianism, N - narcissism, P - psychopathy, DS - direct sadism, VS vicarious sadism. All variables have a theoretical range between 1 and 5, except the RPQ which has a range between 0 and 2 . All correlations $\geq .15$ were significant at $p<.001$.

Correlations between the dark traits and reactive and proactive aggression were generally small or moderate, with somewhat higher correlations with proactive aggression (Table 1). The correlation between proactive aggression and SSIS sadism was the highest, but still moderate. Correlations between the dark traits and alcohol use and binge drinking were all small, with somewhat higher correlations with binge drinking.

\section{Results of latent profile analysis (LPA)}

According to the results of LPA (Table 2) based on the Dark Triad and Dark Tetrad, the dimensional solution was the best one when only direct or "core" sadism from the VAST was used, i.e. the variable-centered approach is preferred. When the Dark Triad was combined with sadism measured by the SSIS or VAST (using both total scores and subscales scores), two profiles emerged as the best solution. However, the differences between the profiles based on the Dark Tetrad traits were rather quantitative, and not qualitative (see Table 3), suggesting that the variable-centered approach is more appropriate for this combination of measurements. 
In the profiles based on the DTDD + SSIS, the differences in sadism had the highest effect size; in the profiles based on the DTDD + VAST total score, the differences in Machiavellianism and narcissism had the highest effect size; and in profiles based on the DTDD and VAST subscales scores, the differences in narcissism had the highest effect size. Thus, depending on the combination used, different dark traits constitute the magnitude of differences between the extracted profiles.

Table 2

BIC indices for the top 3 proposed profile solutions for the Dark Triad and Dark Tetrad traits

\begin{tabular}{cllccc}
\hline \multicolumn{1}{c}{ Models } & Measures & & \multicolumn{3}{c}{ The best three solutions } \\
\hline \multirow{3}{*}{ Dark Triad } & \multirow{2}{*}{ DTDD } & No. of profiles & 1 & 1 & 1 \\
& & & -4757.60 & -4757.65 & -4754.65 \\
& & & EE & EEV & EVE \\
\hline \multirow{3}{*}{ Nark Tetrad profiles } & 2 & 2 & 2 \\
& \multirow{2}{*}{ DTDD + SSIS } & & -6254.00 & -6269.98 & -6270.77 \\
& & & VVE & EVE & EEE \\
\hline \multirow{3}{*}{ Dark Tetrad } & DTDD + VAST & No. of profiles & 2 & 2 & 1 \\
& \multirow{2}{*}{ total score } & & -6468.70 & -6470.97 & -6474.62 \\
& & & VVE & EVE & VVV \\
\hline \multirow{3}{*}{ Dark Tetrad } & DTDD + Direct & No. of profiles & 1 & 1 & 1 \\
& & & -6501.10 & -6501.11 & -6501.11 \\
& sadism & & EEE & EEV & EVE \\
\hline \multirow{3}{*}{ Dark Tetrad } & DTDD + & No. of profiles & 2 & 2 & 3 \\
& Direct sadism + & & -8089.60 & -8098.50 & -8107.52 \\
& Vicarious sadism & & VVE & VEE & VVE \\
\hline
\end{tabular}

Note. In the R package "mclust" higher BIC values indicate a better model solution; EEE - ellipsoidal distribution, equal volume, equal shape, equal orientation; EEV - ellipsoidal distribution, equal volume, equal shape, variable orientation; EVE - ellipsoidal distribution, equal volume, variable shape, equal orientation; VVE - ellipsoidal distribution, variable volume, variable shape, equal orientation; VVV - ellipsoidal distribution, variable volume, variable shape, variable orientation; VEE - ellipsoidal distribution, variable volume, equal shape, equal orientation.

Table 3

T-tests of differences in the dark traits between the extracted profiles

\begin{tabular}{|c|c|c|c|}
\hline Dark traits & DTDD + SSIS & $\begin{array}{c}\text { DTDD + VAST } \\
\text { total score }\end{array}$ & $\begin{array}{c}\text { DTDD + Direct sadism } \\
\text { + Vicarious sadism }\end{array}$ \\
\hline Machiavellianism & $-9.32^{\star \star \star}(0.76)$ & $-16.65^{\star * *}(1.32)$ & $-10.51^{\star * \star}(0.84)$ \\
\hline Narcissism & $-11.30^{\star * *}(0.93)$ & $-21.31^{* * *}(1.69)$ & $-17.55^{\star \star \star}(1.39)$ \\
\hline Psychopathy & $-9.95^{\star * *}(0.82)$ & $-8.15^{\star * \star}(0.64)$ & $-11.21^{\star \star \star}(0.89)$ \\
\hline Sadism (SSIS) & $-29.29^{* * *}(2.16)$ & - & - \\
\hline Sadism (VAST total) & - & $-7.59^{\star * \star}(0.59)$ & - \\
\hline Direct sadism (VAST) & - & - & $-10.18^{\star \star \star}(0.80)$ \\
\hline Vicarious sadism (VAST) & - & - & $-1.15(0.09)$ \\
\hline
\end{tabular}

Note. $d f=622$; Cohen's $d$ as a measure of the effect size is in parentheses; ${ }^{\star * \star} p<.001$. 
As can be seen in Figure 1, all of the extracted profiles could be characterized as either low or high dark traits profiles, since the differences in all traits were significant. The exception was the difference in direct sadism, when the DTDD and two sadism subscales from the VAST were combined (Table 3).

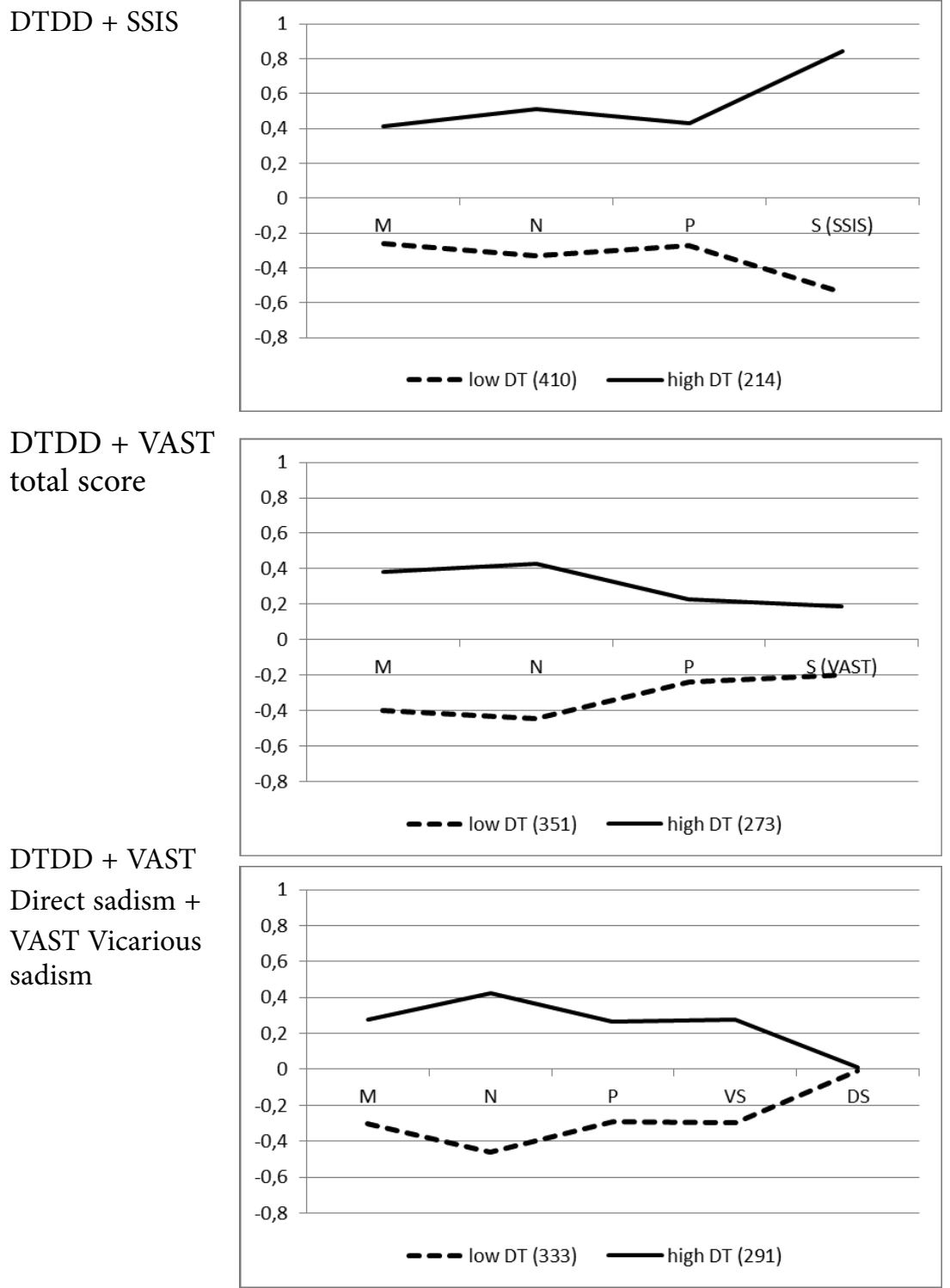

Figure 1. Dark traits profiles.

Note. M - Machiavellianism, N - narcissism, P - psychopathy, S - sadism, VS - vicarious sadism, DS - direct sadism. Standardized scores are on the Y-axis. 
Since the inclusion of sadism into the dark traits constellation leads to the extraction of profiles, we tested whether sadism measured by the SSIS and by the VAST could be taxonic. The results of LPA have shown that three profiles could be extracted on the SSIS scores (BIC $=-1553.95)$ and two profiles on the VAST total scores $(\mathrm{BIC}=-1755.34)$. The second best solutions based on BIC also supported the extraction of more than one profile. These results suggested that sadism might be categorical. However, other traits are clearly dimensional. LPA on the psychopathy, Machiavellianism, and narcissism scores resulted in one profile for all three dimensions $(\mathrm{BIC}=-1782.710 ;-1782.707$, -1782.707 , respectively), which implies that these traits are dimensional. Given these results, it is not surprising that the variable-centered approach better describes the relations between the dark traits.

There were significant sex differences in the profiles based on all three combinations (DTDD + SSIS $\chi_{(1)}^{2}=16.25, p<.001$; DTDD + VAST total score $\chi_{(1)}^{2}=8.37, p<.01$; DTDD + direct sadism + vicarious sadism $\chi_{(1)}^{2}=22.88$, $p<.001$ ), with men having high dark traits profiles more frequently. Significant age differences were found between the profiles based on the combination of the DTDD and VAST total score $\left(t_{(600)}=3.25, p<.001\right)$ and the DTDD and VAST subscales scores $\left(t_{(600)}=3.93, p<.001\right)$, with younger people having high dark traits profiles more frequently. However, when the combination of the DTDD and SSIS was used, no significant age differences between the profiles were found $\left(t_{(600)}=1.66, p=.097\right)$.

\section{Profiles agreement}

The measures of the agreement between different classification solutions were also examined. The measure of the agreement based on the comparison between the DTDD + VAST total score and DTDD + direct sadism + vicarious sadism (kappa $=.59, p<.001$ ) was moderate. Low measures of agreement were obtained for the comparison between the DTDD + VAST and DTDD + SSIS $(\mathrm{kappa}=.36, p<.001)$, and the comparison between DTDD + direct sadism + vicarious sadism and DTDD + SSIS (kappa $=.28, p<.001$ ). Thus, it can be concluded that the classification depends largely upon the used sadism measure. Furthermore, given the sex and age effects, these variables will be controlled in further analysis.

\section{Criterion validation of the profiles}

Within each combination of measurements, the profiles differed in both reactive and proactive aggression, with high dark traits profiles being associated with higher scores on aggression (Table 4). Thus, these differences were moderate in the case of both reactive and proactive aggression combined 
with the SSIS, while they were moderate only in the case of proactive aggression combined with the VAST total score. The differences in alcohol use and binge drinking were significant only between the profiles based on DTDD + SSIS, with the members of high dark traits also having higher scores on alcohol use and binge drinking. All differences in alcohol-related behaviours were small in terms of the effect size.

Table 4

F-tests of differences in risky behaviour variables between the dark traits profiles

\begin{tabular}{llll}
\hline Risky behaviours & DTDD + SSIS & $\begin{array}{l}\text { DTDD + VAST total } \\
\text { score }\end{array}$ & $\begin{array}{l}\text { DTDD + Direct sadism + } \\
\text { Vicarious sadism }\end{array}$ \\
\hline Reactive aggression $_{(1,598)}$ & $51.79^{* * *}(0.08)$ & $30.78^{* * *}(0.05)$ & $24.17^{* * *}(0.04)$ \\
Proactive aggression $_{(1,598)}$ & $79.98^{* * *}(0.12)$ & $50.10^{* * *}(0.08)$ & $29.97^{* * *}(0.05)$ \\
Alcohol use $_{(1,587)}$ & $8.22^{* *}(0.01)$ & $1.54(0.00)$ & $0.16(0.00)$ \\
Binge drinking $_{(1,587)}$ & $13.53^{* * *}(0.02)$ & $2.32(0.00)$ & $2.60(0.00)$ \\
\hline
\end{tabular}

Note. $d f s$ are in parentheses next to the names of risky behaviours; sex and age were entered as covariates in order to control for their effects; the measure of the effect size $\left(\eta_{\mathrm{p}}{ }^{2}\right)$ is in parentheses; ${ }^{* * *} p<.001$.

Additionally, we tested the incremental validity of profiles over and above the dark traits in the prediction of aggression and alcohol variables. The results support the claim that there is no significant incremental validity: $\Delta R^{2}$ for proactive aggression, reactive aggression, drinking, and binge drinking were $.010, .005, .003$, and .001 , respectively, if they are predicted based on DTDD + SSIS scores, and .003, .002, .002, and .001, respectively, if they are predicted based on DTDD + VAST scores. Thus, these results support the use of the variable-centered approach over the person-centered approach in studying the dark traits.

\section{Discussion}

The aim of this research was to determine whether the person-centered or variable-centered approach is better at describing the covariance between the Dark Triad and Dark Tetrad traits. In the case of the Dark Triad, the results of LPA are clear. LPA revealed a one-profile solution, supporting the dimensional approach as the more appropriate one. The results are in line with the previous study using LPA (Kam \& Zhou, 2016), in which parallel shapes of the Dark Triad profile solutions were extracted. In the case of the Dark Tetrad traits, for each combination of measures, the extracted profiles differed quantitatively and not qualitatively, i.e. the profiles with high and low dark traits were extracted. Since differences between the profiles were quantitative, the variable-centered approach seemed to be preferred when the Dark Tetrad traits are of interest as well. 
Furthermore, the results of our study suggest that sadism might be categorical. A previous study in which taxometric analysis was used showed that sadism might be taxonic among women, but not among men (Tran et al., 2018). Although it might be taxonic, the inclusion of sadism into the dark traits constellation resulted in quantitative and not qualitative differences among profiles.

In each combination of profiles, high dark traits profiles counted a smaller number of participants. High dark traits groups included more males, which is in line with the previous findings, showing that men from the general population tend to be higher on dark traits than women (e.g., Dinić et al., 2018). Additionally, participants with high dark traits profiles were younger, except in the combination of DTDD + SSIS, where there were no significant age differences.

The agreement between profiles based on the combination of the DTDD and different measures of sadism was rather low or moderate. This finding is in accordance with the effect sizes of the differences in each dark trait in the extracted profiles. Thus, the profile membership seems to be significantly affected by the measure of sadism. According to the authors of the VAST scale (Paulhus \& Jones, 2015), the direct sadism subscale and SSIS scale should overlap and measure the same form of sadism. However, when DTDD + direct sadism combination was used, one profile was extracted, whereas the DTDD + SSIS scale combination resulted in a two-profile solution. These results imply that the content of direct sadism from the VAST and SSIS scale might not be as similar as the authors suggested. This is also supported by the moderate and not high correlation between these two scales in our research. However, a valid conclusion regarding the similarity of these two measures requires a further examination.

The next question concerns the external validation of both the variable and person-centered approaches. All correlations between the dark traits and risky behaviours were rather low or moderate, and the highest correlation was obtained between the SSIS sadism and proactive aggression. This is also evident in the differences between profiles. Namely, only in the DTDD + SSIS combination, the low and high dark traits profiles differed in all risky behaviours, but the major differences were found in proactive aggression. Since the high dark traits group in the DTDD + SSIS combination was dominantly characterized by high sadism, the results are in line with the previous findings regarding the relations between sadism and unprovoked aggression (e.g., Reidy et al., 2011). Thus, the information obtained from the external validity of the two approaches is the same. Since the results of LPA already supported the variable-centered approach, we could conclude that no new information regarding external validity could be obtained by the personcentered approach. 
It should be noted that the profiles based on DTDD + VAST differed only in terms of aggression, and not alcohol use. However, the main differences between the profiles based on the DTDD + VAST scores were in narcissism and Machiavellianism, which has to be taken into account when interpreting the results. Both narcissism and Machiavellianism are thought to be the "lighter" dark traits, with both of them showing low associations with substance abuse (e.g., Jonason et al., 2010).

There are several limitations of this study. First, the short measure was used for assessing the Dark Triad. We used the DTDD as the most popular and most frequently used measure of the Dark Triad, but correlations between the DTDD scales were rather high, which raises the concerns regarding the uniqueness of these scales. In previous studies, correlations between DTDD scales were also high and in the same range as in our study (e.g., Dinić et al., 2018). In a previous study in which LPA was conducted (Kam \& Zhou, 2016) another short measure was used - the Short Dark Triad (SD3: Jones \& Paulhus, 2014). In further studies, the full-length measures of the Dark Triad should be applied, in order to compare the results. Second, the alpha reliability of psychopathy scale scores is low, and this could affect the results. Third, although the SSIS and VAST are the most commonly used measures of sadism, Buckles and Paulhus (2014) have recently proposed a new version of the VAST - the Comprehensive Assessment of Sadistic Tendencies (CAST), with three subscales encompassing verbal, physical, and vicarious sadism. Moreover, Plouffe, Saklofske, and Smith (2017) have proposed the Assessment of Sadistic Personality (ASP, for Serbian adaptation see Dinić et al., under review). Both measures seem promising, so the recommendation for further studies is to include other measures of sadism and examine whether the use of different measures will affect the results. Finally, since this study included the participants from the general population, further studies should consider examining latent profiles in forensic or clinical population. Some preliminary results indicated that two qualitatively different Dark Tetrad profiles on the violent offenders' sample can be extracted (Dinić, Branovački, Sadiković, Oljača, \& Baić, 2019), but further examination is warranted.

Our study was conducted as an attempt to examine the dark traits from an approach different than studying each of these traits as separate entities. The variable-centered and person-centered approaches are viewed as complementary strategies that provide different perspectives on the phenomenon of interest (e.g., Zyphur, 2009). Our study has shown that the variable-centered approach is better in describing the dark traits, at least when the DTDD was used. However, our study has also shown that the profile solutions are equally informative in terms of external validity as the variable-centered approach. These findings suggest that the variable-centered approach gives a parsimonious interpretation of the data. 


\section{References}

Asendorpf, J., \& Denissen, J.J.A. (2006). Predictive validity of personality types versus personality dimensions from early childhood to adulthood: Implications for the distinction between core and surface traits. Merrill-Palmer Quarterly, 52(3), 486-513. doi:10.1353/mpq.2006.0022

Bergman, L.R., \& Trost, K. (2006). The person-oriented versus the variable-oriented approach: Are they complementary, opposites, or exploring different worlds. Merrill-Palmer Quarterly, 52(3), 601-632. doi:10.1353/mpq.2006.0023

Buckels, E.E., \& Paulhus, D.L. (2014). Comprehensive Assessment of Sadistic Tendencies (CAST). Vancouver, Canada: University of British Columbia. Unpublished instrument.

Buckels, E.E., Jones, D.N., \& Paulhus, D.L. (2013). Behavioral confirmation of everyday sadism. Psychological Science, 24(11), 2201-2209. doi:10.1177/0956797613490749

Chabrol, H., Melioli, T., Van, L.N., Rodgers, R., \& Goutaudier, N. (2015). The Dark Tetrad: Identifying personality profiles in high-school students. Personality and Individual Differences, 83, 97-101. doi:10.1016/j.paid.2015.03.051

Chabrol, H., Van, L.N., Rodgers, R., \& Séjourné, N. (2009). Contributions of psychopathic, narcissistic, Machiavellian, and sadistic personality traits to juvenile delinquency. Personality and Individual Differences, 47(7), 734-739. doi:10.1016/j. paid.2009.06.020

Cohen, J. (1988). Statistical power analysis for the behavioral sciences. New York, NY: Routledge Academic.

Dinić, B., Branovački, B., Sadiković, S., Oljača, M., \& Baić, V. (2019). Dark Tetrad profiles in violent offenders. Poster presented at the Conference of International Society for the Study of Individual Differences - ISSID 2019, Florence, Italy.

Dinić, B.M., Bulut, T., Petrović, B., \& Wertag, A. (under review). A test of three sadism measures: Short Sadistic Impulse Scale, Varieties of Sadistic Tendencies, and Assessment of Sadistic Personality. Manuscript under review.

Dinić, B.M., \& Raine, A. (2019). An Item Response Theory Analysis and further validation of the Reactive-Proactive Aggression Questionnaire (RPQ): The Serbian adaptation of the RPQ. Journal of Personality Assessment, 1-11. doi:10.1080/002 23891.2019.1573430

Dinić, B.M., \& Wertag, A. (2018). Effects of Dark Triad and HEXACO traits on reactive/proactive aggression: Exploring the gender differences. Personality and Individual Differences, 123, 44-49. doi:10.1016/j.paid.2017.11.003

Dinić, B.M., Petrović, B., \& Jonason, P.K. (2018). Serbian adaptations of the Dark Triad Dirty Dozen (DTDD) and Short Dark Triad (SD3). Personality and Individual Differences, 134, 321-328. doi:10.1016/j.paid.2018.06.018

Fraley, C., Raftery, A.E., \& Scrucca, L. (2012). mclust version 4 for R: Normal mixture modeling for model-based clustering, classification, and density estimation (Technical Report No. 597). Washington: University of Washington - Department of Statistics.

Furnham, A., Richards, S.C., \& Paulhus, D.L. (2013). The Dark Triad of personality: A 10 year review. Social and Personality Psychology Compass, 7(3), 199-216. doi:10.1111/spc3.12018 
Jonason, P.K., \& Webster, G.D. (2010). The Dirty Dozen: A concise measure of the Dark Triad. Psychological Assessment, 22(2), 420-432. doi:10.1037/a0019265

Jonason, P.K., Koenig, B.L., \& Tost, J. (2010). Living a fast life. Human Nature, 21(4), 428-442. doi:10.1007/s12110-010-9102-4

Jones, D.N., \& Paulhus, D.L. (2014). Introducing the Short Dark Triad (SD3): A brief measure of dark personalities. Assessment, 21(1), 28-41. doi:10.1177/1073191113514105

Kam, C.C.S., \& Zhou, M. (2016). Is the Dark Triad better studied using a variable- or a person-centered approach? An exploratory investigation. PLOS ONE, 11(8), doi:10.1371/journal.pone.0161628

Meehl, P.E. (1992). Factors and Taxa, traits and types, differences of degree and differences in kind. Journal of Personality, 60(1), 117-174. doi:10.1111/j.1467-6494.1992.tb00269.x

Meyer, J.P., \& Morin, A.J.S. (2016). A person-centered approach to commitment research: Theory, research, and methodology. Journal of Organizational Behavior, 37(4), 584-612. doi:10.1002/job.2085

Muris, P., Merckelbach, H., Otgaar, H., \& Meijer, E. (2017). The malevolent side of human nature: A meta-analysis and critical review of the literature on the Dark Triad (narcissism, Machiavellianism, and psychopathy). Perspectives on Psychological Science, 12(2), 183-204. doi:10.1177/1745691616666070

O'Meara, A., Davies, J., \& Hammond, S. (2011). The psychometric properties and utility of the Short Sadistic Impulse Scale (SSIS). Psychological Assessment, 23(2), 523-531. doi:10.1037/a0022400

Paulhus, D.L., \& Jones, D.N. (2015). Measures of dark personalities. In G.J. Boyle, D.H. Saklofske, \& G. Matthews (Eds.), Measures of Personality and Social Psychological Constructs. (pp. 562-594). San Diego, CA, USA: Elsevier Academic Press. doi:10.1016/b978-0-12-386915-9.00020-6

Paulhus, D.L., \& Williams, K.M. (2002). The Dark Triad of personality: Narcissism, Machiavellianism, and psychopathy. Journal of Research in Personality, 36(6), 556-563. doi:10.1016/s0092-6566(02)00505-6

Peat, J. (2001). Health science research: A handbook of quantitative methods. Sydney: Allen and Unwin.

Plouffe, R.A., Saklofske, D.H., \& Smith, M.M. (2017). The Assessment of Sadistic Personality: Preliminary psychometric evidence for a new measure. Personality and Individual Differences, 104, 166-171. doi:10.1016/j.paid.2016.07.043

Raftery, A.E. (1995). Bayesian model selection in social research. Sociological Methodology, 25, 111-163. doi:10.2307/271063

Raine, A., Dodge, K., Loeber, R., Gatzke-Kopp, L., Lynam, D., Reynolds, C., . . Liu, J. (2006). The Reactive-Proactive Aggression Questionnaire: Differential correlates of reactive and proactive aggression in adolescent boys. Aggressive Behavior, 32(2), 159-171. doi:10.1002/ab.20115

Reidy, D.E., Foster, J.D., \& Zeichner, A. (2010). Narcissism and unprovoked aggression. Aggressive Behavior, 36(6), 414-422. doi:10.1002/ab.20356 
Reidy, D.E., Zeichner, A., \& Seibert, L.A. (2011). Unprovoked aggression: Effects of psychopathic traits and sadism. Journal of Personality, 79(1), 75-100. doi:10.1111/j.1467-6494.2010.00691.x

Sadiković, S., Fesl, D., \& Čolović, P. (2016). Tipovi ličnosti na novoj teritoriji: Analiza latentnih profila u prostoru tri psiholeksička modela ličnosti [Personality types on new ground: Latent profile analysis based on three psycholexical models of personality]. Primenjena Psihologija, 9(1), 41-61. doi:10.19090/pp.2016.1.41-61

\title{
Mračne crte kroz pristup usmeren na varijablu i na osobu i njihove relacije sa nekim rizičnim ponašanjima
}

\author{
Bojana M. Dinić, Mina Velimirović, Selka Sadiković \\ Odsek za psihologiju, Filozofski fakultet, \\ Univerzitet u Novom Sadu, Srbija
}

Cilj ovog istraživanja je ispitivanje koji pristup bolje opisuje kovarijansu između crta Mračne trijade i Mračne tetrade na opštoj populaciji - pristup usmeren na osobu ili pristup usmeren varijablu. Na uzorku od 624 ispitanika (48.2\% muškaraca), primenjeni su upitnici Mračne trijade (Dark Triad Dirty Dozen - DTDD) i sadizma (Short Sadistic Impulse Scale - SSIS i Varieties of Sadistic Tendencies Scale - VAST) za procenu mračnih crta, a Upitnik reaktivne i proaktivne agresije (Reactive Proactive Questionnaire - RPQ) i pitanja o upotrebi alkohola za procenu kriterijumske validnosti. U cilju testiranja koji pristup bolje opisuje kovarijansu između mračnih crta, primenjena je analiza latentnih profila. Rezultati ukazuju na to da se na osnovu mračnih crta može izdvojiti jedan profil ili dva koja se razlikuju kvantitativno (profili s niskim i visokim mračnim crtama), što sugeriše da je pristup usmeren na varijablu više primeren u odnosu na pristup usmeren na osobu. U slučaju Mračne tetrade, pripadnost profilu zavisi od toga koja je mera sadizma korišćena, tj. saglasnost između profila je umerena. Profil s visokim mračnim crtama baziran na kombinaciji sa SSIS skalom sadizma karakteriše visoka agresija i upotreba alkohola, dok isti profil s visokim crtama, ali baziran na kombinaciji sa VAST merom sadizma, karakteriše samo viša sklonost agresiji.

Ključne reči: Mračna trijada, Mračna tetrada, mračne crte, sadizam, analiza latentnih profila, agresija, upoteba alkohola 